\title{
Analysis of infection with fungi of the genus Fusarium seed and vegetative organs of crops
}

\author{
Natalya Ryabova ${ }^{1(0000-0002-9172-253)}$, Tatiana Tupolskikh ${ }^{1(0000-0003-0581-8058)}$, Valentins Serdyuk \\ 1(0000-0003-3538-3358)*, and Nadezhda Gordeeva ${ }^{3(0000-0003-2038-5502)}$
}

${ }^{1}$ Don State Technical University, 1, Gagarin Sq., 344003, Rostov-on-Don, Russia

\begin{abstract}
Studying the specific and intraspecific structure of populations of causative agents of Fusarium ear of grain crops. The results of experimental studies of samples of grain crops affected by microscopic fungi p.Fusarium. The analysis of the infection of grains, stems and roots of various types of cereals with mitospores fungi was carried out. The variability of pathogenic properties of Fusarium fungi depending on the part of the ear is shown. The results of the research are important for the targeted diagnosis of fusarium of grain crops and plants of the ear.
\end{abstract}

\section{Introduction}

Fusarium fungi can cause serious damage to important agricultural crops. The defeat of grain crops by fusarium leads to a decrease in the yield and quality of grain (the nature, weight of 1000 grains decreases, the baking quality of flour deteriorates) contamination of grain with secondary metabolites. Infected seeds do not germinate or give a weakening of the seedlings, a high degree of infection leads to a hollow-wose. Lots of grain containing more than $10 \%$ of suds infuted with fusarium fungi are not suitable for seed purposes. Fusarium, dangerous because fungi in the life secrete dangerous secondary metabolites-mitotoxins Grain becomes unfit for food and livestock fud.At the beginning of the 20th century, the inhabitants of the Central Region and Southern Urals, were heavily poisoned with grain contaminated with fungus, which las led to a massive case of alimentary toxicity which alters blood composition and causes serious. Fungi of the genus Fusarium live as saprotrophs in the soil, on wood and plant residues, and are also parasites of higher plant. Sources of infection are plant residues, infected soil, parts of plants where the fungus is present in the form of fruit bodies or mycelium. Chamydospores can persist in the soil for up to several years and germinate under favorable conditions. The pathogenic complex of fusarium pathogens includes a group of the most frequently isolated species, presented in table 1.

Maximum permissible concentrations of the main groups of fusariotoxins released during the life of fusarium fungi [19]: DON - (MPC 0.7-1 mg per $1 \mathrm{~kg}$ of grain); T_2 toxin - (MPC $0.1 \mathrm{mg}$ per $1 \mathrm{~kg}$ of grain); ZEN - (MPC $0.2-1 \mathrm{mg}$ per $1 \mathrm{~kg}$ of grain).

\footnotetext{
* Corresponding author: valy11164@mail.ru
} 
Table 1. Mycotoxicological characteristics of fusarium pathogens.

\begin{tabular}{|l|l|c|}
\hline \multicolumn{1}{|c|}{ Species } & \multicolumn{1}{|c|}{ Description } & Mycotoxin \\
\hline F. sporotrichioides & $\begin{array}{l}\text { It is manifested on subs, spikelet scales of cereals due to the } \\
\text { ability to form chlamydospores, it is resistant to various } \\
\text { environmental conditions. }\end{array}$ & T-2 \\
\hline F. graminearum & $\begin{array}{l}\text { Om of main causative agents of fusarium ear of wheat, barley, } \\
\text { rye. It affects the seeds, stems and roots of plants. }\end{array}$ & $\begin{array}{c}\text { DON } \\
\text { ZEN }\end{array}$ \\
\hline F. avenaceum & $\begin{array}{l}\text { A plant pathogen with variety of hosts, it can live up to 80 } \\
\text { genera of plants. }\end{array}$ & MON \\
\hline F. culmorum & $\begin{array}{l}\text { It affects a wide range of host plants, mainly cereals and } \\
\text { various grasses. Also the pathogen is released from sugar } \\
\text { beets, clover, strawberries, and potatoes. }\end{array}$ & DON \\
\hline F. zxysporum & $\begin{array}{l}\text { Causes fusarium root rot. It is an important pathogen of } \\
\text { vascular wilt worldwide. }\end{array}$ & MON \\
\hline F. proliferatum & $\begin{array}{l}\text { It affects the aboveground parts of plants, producing various } \\
\text { mycotoxins that are dangerous for humans and animals. It is } \\
\text { also one of the causes of red rood rot or sudden soy death } \\
\text { syndrome. }\end{array}$ & FUM \\
\hline F. solani & $\begin{array}{l}\text { It is widely distributed in the soil, causing tuberous, root and } \\
\text { stem rot of plants. }\end{array}$ & MON \\
\hline F. poae & $\begin{array}{l}\text { It affects wheat, rye, is associated with human and animal } \\
\text { toxicoses, and produces mycotoxins. }\end{array}$ & $\begin{array}{l}\text { NIV } \\
\text { DAS }\end{array}$ \\
\hline F. langsethiae & $\begin{array}{l}\text { They are a producer dangerous mycotoxins and the presence } \\
\text { of pathogens of grain in the complex is necessary. Distributed } \\
\text { almost throughout the European part of the Russian } \\
\text { Federation. }\end{array}$ & $\begin{array}{c}\text { T-2 } \\
\text { DAS }\end{array}$ \\
\hline F. verticillioides & $\begin{array}{l}\text { It is one of the main pathogens of maize, but it also parasitizes } \\
\text { other crops. }\end{array}$ & FUM \\
\hline
\end{tabular}

Designations: DON - deoxynivalenol; MON - moniliformin; NIV - nivalenol; T-2 toxin; FUM fumonisins; DAS - diacetoxyscirpenol, ZEN - Zearalenone.

External characteristics of the ear affected by fusarium are represented by photographs:
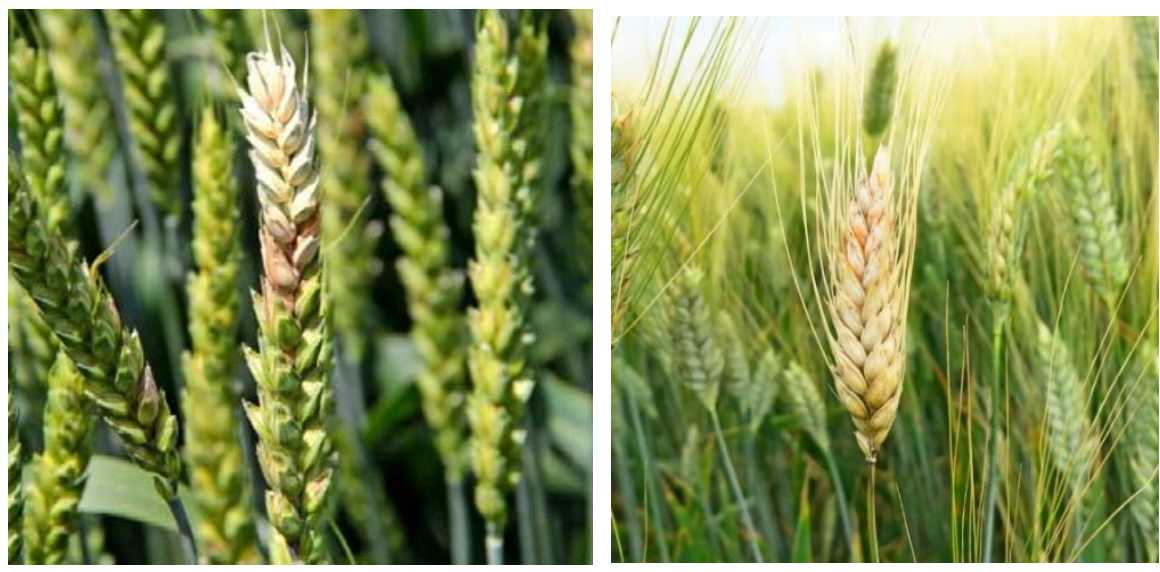

Fig.1. Wheat ear fusarium.

The main symptoms are pink or red-and-brown swelling on the surface. 


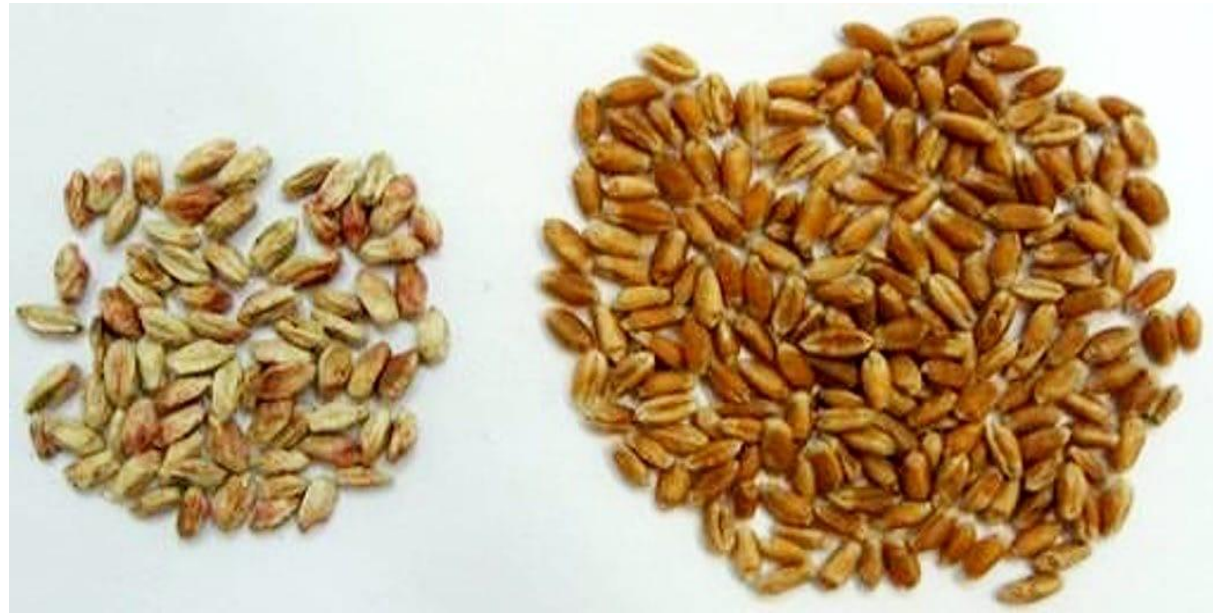

Fig. 2. Differnce between Fusarium - affected grain and heaithy grain [17].

Most of the grains are wrinkled crooked, with pointed barrels and heavily depressed grooves. The grain is writish, chalky [14]. There may be spots and a pink stain on the surface. Sometimes obvius signs of grain damage may be absent this type damage is the most dangerous.

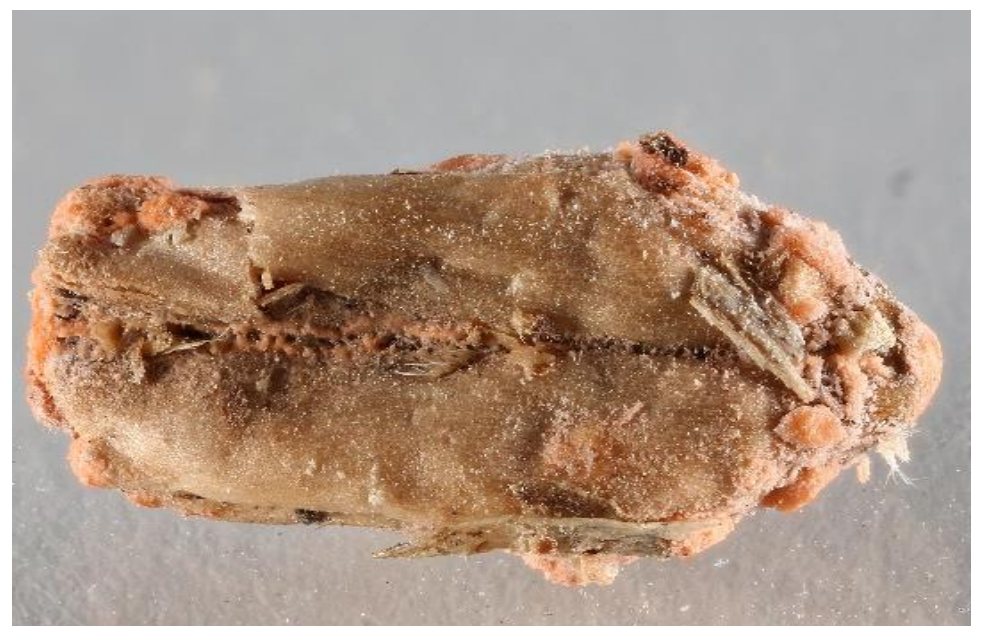

Fig. 3. Grain affected by F. graminearum fungus. The picture was taken by the staff of the VNIIKR laboratory.

On the surface of the grain, a link pink coating is visible, which consist of sporodochia of the fungus with spores.

\section{Materials and Methods}


From June 2019 to December 2020 samples of seeds and parts of the plant are sent to the laboratory All-Russian Plant Quarantine Center (VNIIKR) received samples of seeds and plant parts of wheat, barley, oats, sunflower, sorghum, corn, and soy.

Samples were taken from certain samples. The study was conducted by a biological method, which is used to detect external or internal contamination of the plant. The pathogen was released in a humid chamber.

Seeds (200-300 from each sample) washed under running water for 10 minutes, and plant parts for 2-3 minutes. The studied grains or plant parts are subjected to surface sterilization with spirit - the grain is immersed in spirit for 2-3 minutes, plant tissue - for 2-3 seconds, and then washed twice in sterile water[12].

Grains are laid out in an amount of 5-10 pieces in Petri dishes on a growth medium (CHA $2 \%$ ) or filter paper using tweezers, which are periodically sterilized in a burner flame. Plant parts are cut with sterile dissecting needles or a scalpel into small pieces $(2-3 \mathrm{~cm})$, which are laid out on sterile filter paper or medium. Petri dishes with analyzed samples are incubated in a thermostat / humid chamber at a temperature of $23-25^{\circ} \mathrm{C}$ with alternating light-dark mode for 12 hours. In 5-7 days identification shall be carried out [12]. To identify the pathogen by microscopy and morphometry, sporulation of the fungus is placed on the slide into a drop of water with a dissecting needle. Cover the glass and view under the microscope from 10x magnification [11]. Identification occurs with the help of auxiliary literature [2].

In 2019/2020, 1,100 samples of both seed and parts of wheat, barley, maize, oats, soybean, sorghum, sunflower and other crops were examined. Fusarium was detected in 150 cases.

In wheat seed research, F. poae (14.00\%) and F. sporotrichioides $(6.00 \%)$ were the most prominent species of Fusariosis. Less identified were F. verticillioides $(2.67 \%)$, F.proliferatum $(2.00 \%)$ and F. langsethidae $(2.00 \%)$.

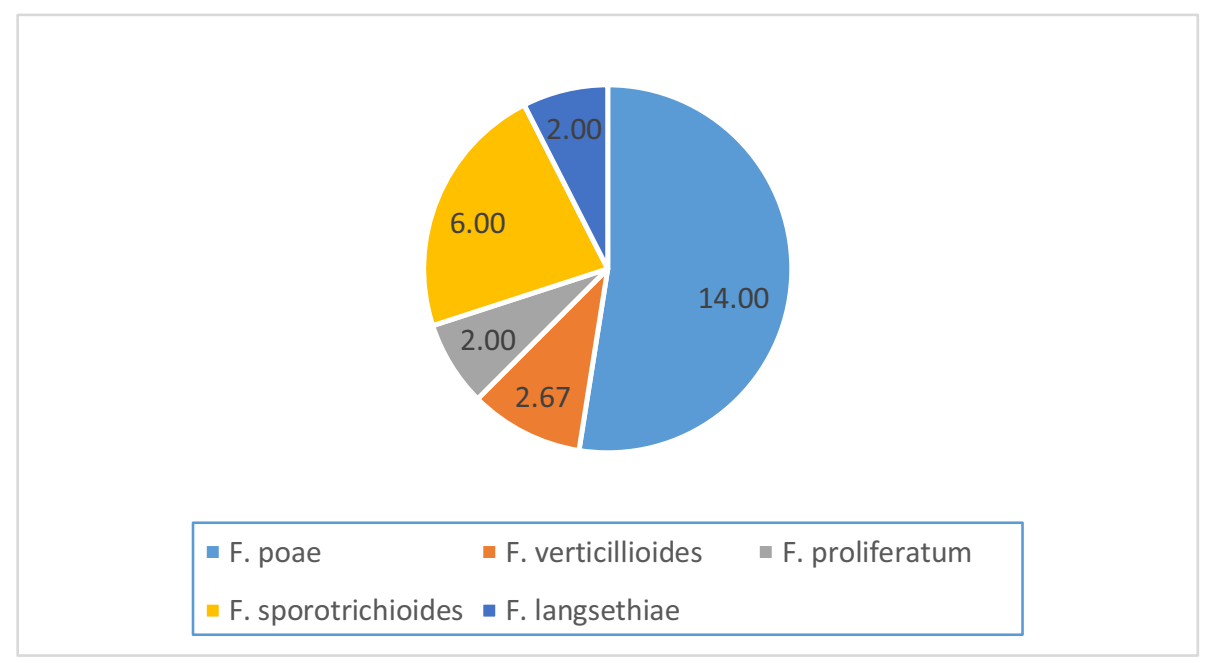

Fig.4. Identification of Fuzarium of Wheat Seeds

The species F. poae and F. sporotrichioides are characterized by wide ecological plasticity and ubiquity.

According to numerous publications, F. poae and F. sporotrichioides are characterized by wide ecological plasticity and ubiquity [6], [13]. F. poae is reliably recorded on cereals and 
sunflowers, and F. sporotrichioides is able to parasitize a wide range of hosts [11]. F. proliferatum, F. verticillioides refer to the Gibberella fujikuroi fungus complex and are observed in the southern regions, mostly maize, but are also found on wheat $[6,7]$. F. langsethiae is also derived from wheat, oat, barley, and has some similarities to F. poae $[14,23]$.

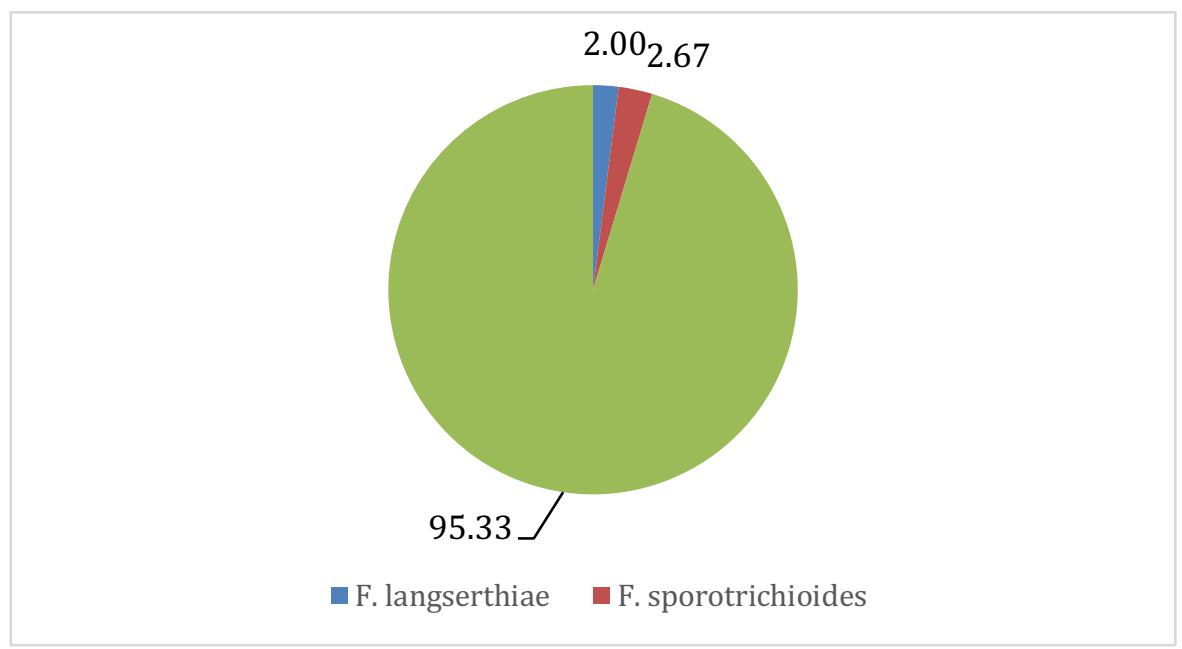

Fig. 5. Detection of Fusarium on Oat Seeds.

In the study of oat seeds the growth of F. sporotrichioides $(2.67 \%)$, F. langserthiae (2\%) was observed.(fig.5) It is established that these species are the main representatives of fusarium fungi in the mycobiota of oats [4].

All samples of plant parts of selected maize $(19,67 \%)$, sunflower $(4,32 \%)$, sorghum $(0.67 \%)$ were infected with F. verticillioides (fig.3). This pathogen most often infects maize, although found in other cultures, causes rots in cobs and stems. Fungi of the Gibberella fujikuroi complex, to which F. verticillioides belongs, are somewhat confined to feeding plants. Some authors believe this is due to the increased attribution of host plant tissue to certain species of fungi $[6,9]$.

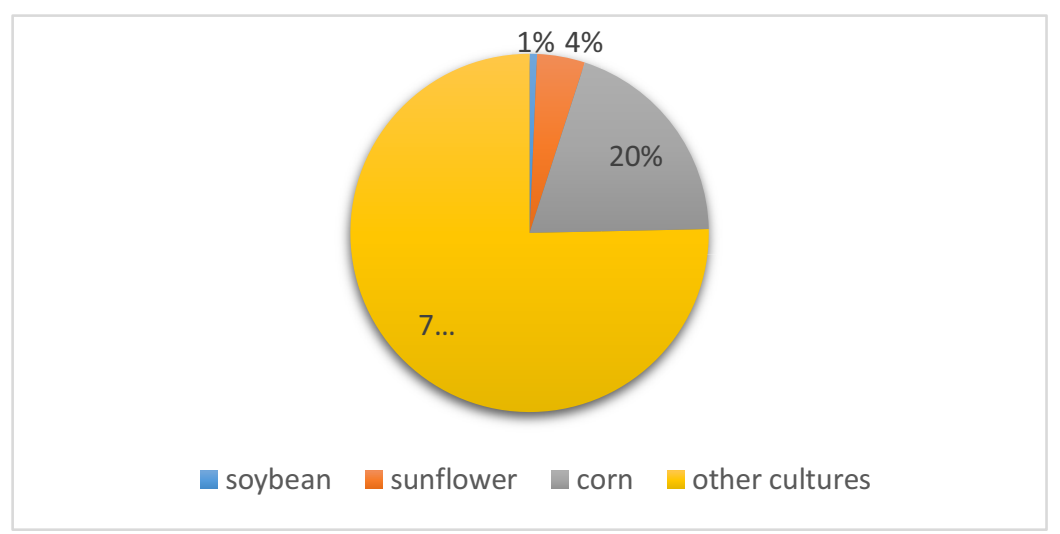

Fig. 6. Detection of occurrence of F. verticillioides in corn, sunflower, and sorghum seeds. 
In the samples of barley seeds, we found two types of fusariasis-F. poae $(0.67 \%)$ and $F$. sporotrichoides $(0.67 \%)$, which is explained by their wide prevalence. Also, F. poae $(0.67 \%)$ was found on soybeans. The growth of F. proliferatum (4\%) was observed on flax seeds. This pathogen is not specific to this crop, but it can be transferred to it from other plants [18].

Table 2. Identification of species of Fusarium on seeds of different crops.

\begin{tabular}{|c|c|c|c|c|c|c|c|c|}
\hline $\begin{array}{l}\text { Fusarium } \\
\text { species }\end{array}$ & $\frac{\vec{E}}{E}$ & 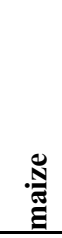 & 㝴 & 气ै &. & 总 & $\overrightarrow{\theta_{n}}$ & 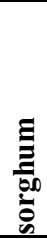 \\
\hline F. poae & + & & & & & + & + & \\
\hline F. langsethiae & + & & & + & & & & \\
\hline $\begin{array}{l}\text { F. } \\
\text { sporotrichioides }\end{array}$ & + & & & + & & + & & \\
\hline F. verticillioides & + & + & + & & & & & + \\
\hline F. proliferatum & + & & & & + & & & \\
\hline F. graminearum & + & & & & & & & \\
\hline
\end{tabular}

\section{Results and discussion}

Thus, maximum species diversity of Fusarios has been identified on wheat, oats, and barley seeds, as p. Fusarium mushrooms are an integral part of the mycobyote of these species.

On corn, sunflower, flax, soybeans, corn and sorghum, one type of fusarium was identified. F. poae and F. verticillioides, F. sporotricioides were most often detected in all the cultures presented, which indicates the ecological plasticity of these fungi species. The most common F. poae and F. verticillioides, F. sporotricioides were found in all the cultures represented, indicating an ecological plasticity of these fungal species.

In sample studies of parts of the wheat plant F. oxysporum and F. solani were the most prominent species of Fusarium. Based on research, F. oxysporum rarely infects wheat grains. Most of the pathogen is on the surface of grain and plant parts, the same applies to the species F. solani.

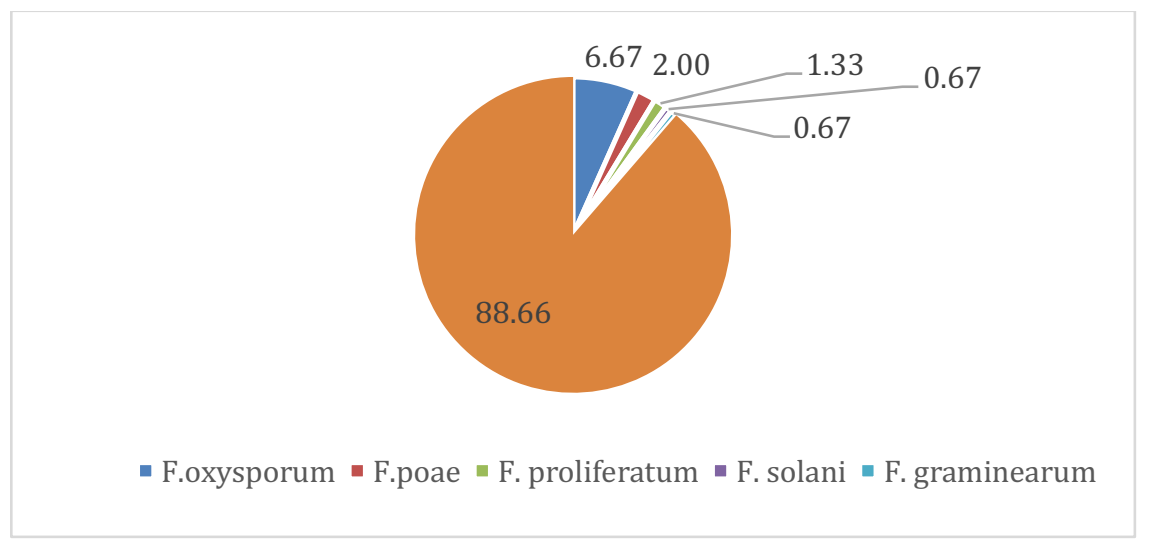

Fig. 7. Discovering Fusarium on the stem of wheat 
To a lesser extent F. proliferatum (1,33\%), F. poae $(2,00 \%)$ and F. graminearum $(0,67 \%)$ (fig.5) were found on the stems and other aboveground parts of the wheat plant. It is know that F. proliferatum can parasitize on aboveground parts of the plant [18]. F. poae и F. graminearum can be in the complex of pathogens that cause Fusarium spotting of wheat leaves and stems. [24,10,19].

Studies of specimens of oat stems showed that the most prominent species of Fusarium are F. охуsporum и F. solani.

As mentioned above, these types of pathogens rarely affect the seeds of crops, mainly parasite the stems, leaves and roots of plants causing root and root rot.

On the aboveground parts of plants such as corn, sunflower, and flax, the detection of fusariosis was isolated. On maize and sunflower, F. verticillioides was detected (5 and 3.35\%, respectively), which is pathogenic associated with these crops [5], [6]. On the leaves and stems of flax, F. oxysporum (2\%) was detected, which is one of the most common pathogens of root and root rot of different crops. We have not conducted studies on the vegetative parts of sorghum and barley plants for the presence of the pathogen under study.

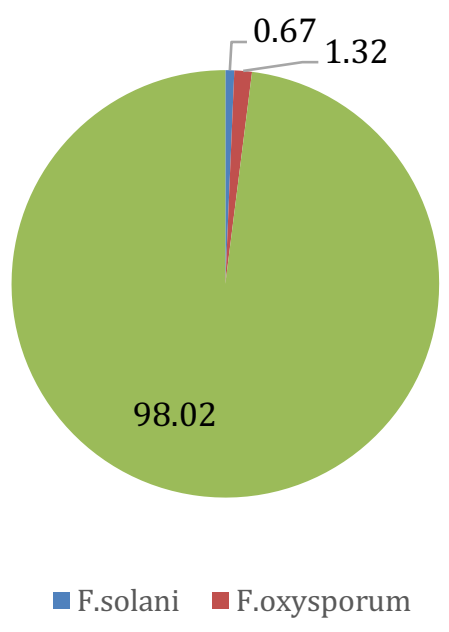

Fig. 8. Discovering Fusarium on the stem of oats.

In the study of wheat root system samples, the most detectable fusarium species were $\mathrm{F}$. oxysporum $(7,33 \%)$, F. solani $(0,67 \%)$ и F. verticillioides $(0,67 \%)$ (fig.5). Fusarium root rot causes a complex of identified fungi $[14,20]$. 


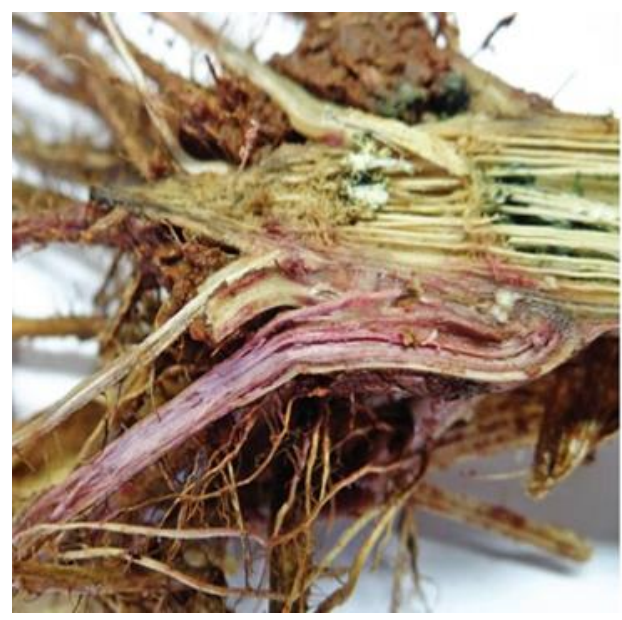

Fig. 9. Symptoms of Fusarius root infection.

On the roots light brown spots and stains, which later proliferate and have a more saturater colour. In severe damage, the roots burrow and break down to form a dry rot.

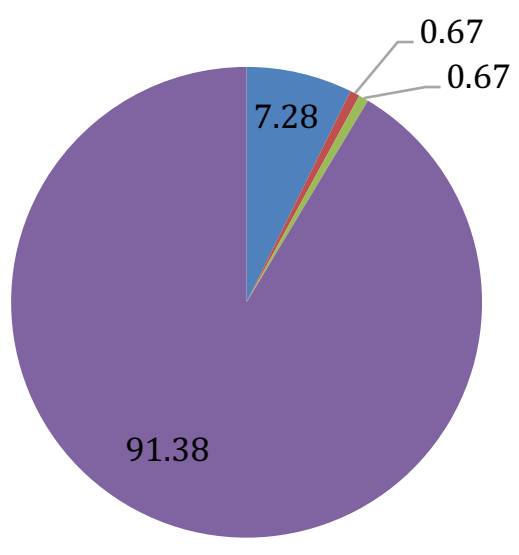

—.oxysporum $\quad$ F. solani $\quad$ F. verticillioides

Fig. 10. Discovering Fusarium on the wheat root.

The study of oat roots showed that the most common species of fusarium are the pathogens of root rot - F. oxysporum (1,99\%), F. solani (0,66\%) (fig. 11). 


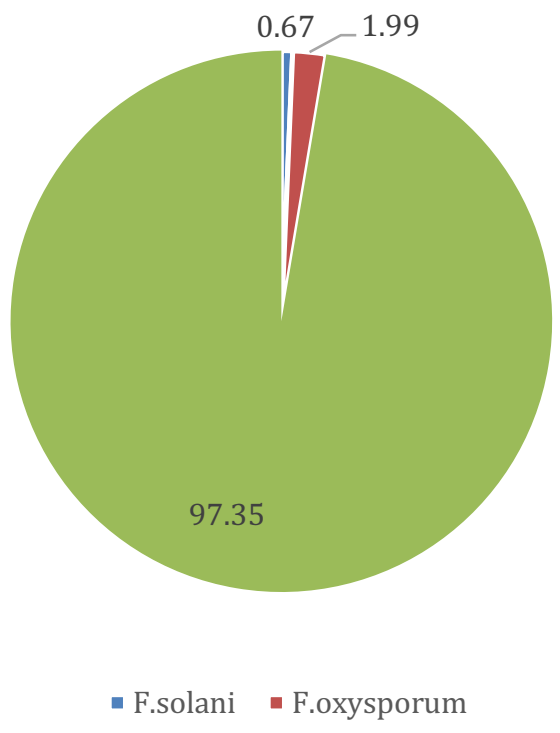

Fig. 11. Discovering Fusarium on oat root.

F. verticillioides (3\%), which acts as a complex of pathogens of plant root rot.

When studying the root rot of flax and corn, the causative agent of fusariosis was not detected, and we did not conduct studies on the roots and plants of sorghum and barley for the presence of the pathogen under study.

Table 3. Identification of Fusarium species on stem (1) and roots (2) of different crops.

\begin{tabular}{|c|c|c|c|c|c|c|c|c|c|c|c|c|}
\hline \multirow[t]{2}{*}{$\begin{array}{c}\text { Species fusarium } \\
\text { Crop }\end{array}$} & \multicolumn{2}{|c|}{$\frac{\vec{\Xi}}{\vec{z}}$} & \multicolumn{2}{|c|}{ 芯 } & \multicolumn{2}{|c|}{ 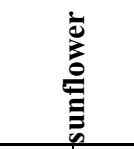 } & \multicolumn{2}{|c|}{ है } & \multicolumn{2}{|c|}{ Е } & \multicolumn{2}{|c|}{ 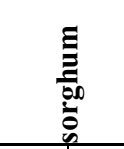 } \\
\hline & (1) & (2) & (1) & (2) & (1) & (2) & (1) & (2) & (1) & (2) & (1) & (2) \\
\hline F. poae & + & & & & & & & & & & & \\
\hline F. verticillioides & & + & + & & + & + & & & & & + & \\
\hline F. proliferatum & + & & & & & & & & & & & \\
\hline F. graminearum & + & & & & & & & & & & & \\
\hline F. oxysporum & + & + & & & & & + & + & + & & & \\
\hline F. solani & + & + & & & & & + & + & & & & \\
\hline
\end{tabular}

\section{Conclusions}

Analyzing the data on the vegetative parts of grain crops infected with p. Fusarium fungi can be observed that most of all crops were infected with F. oxysporum, F. solani and F. verticillioides. These pathogens affected both the roots and stems of plants. Based in the fact that conidia, parts of the mycelium, (in the presence of marsupial sporulation) of fusarium can be preserved in the soil and plant residues, there is a risk that the subsequent crop will be 
affected by fusarium. Spores F. oxysporum, F. solani persist in the soil much longer due to the ability to produce chlamydospores in turn chlamydospores can persist in soil for up to10 $[6,22]$. Fungi F. verticillioides and F. graminearum can persist in the soil and plant residues for up to three years, for example, slowly decomposing parts of a corn plant can be the reserves of infection for many years. [21,25]. Viable conidia are easily brown by wind, water droplets, infection from plant residues plays a much greater role in the development of the disease than inoculum, introduced by different ways of transmission of infection. The risk is also that it is almost impossible to detect the disease in the early stages and that it is not only crop plants can be infected with fusarium, but also wild plants since p. Fusarium fungi have a wide range of host. Especially these factors should be taken into account when using direct seeding technology.

The authors express their gratitude to the head of the Testing Laboratory Shishkanova L. V., senior researcher Kasatkin D. G., agronomist of the first category Shishmanyan N. V. and agronomist Romanchuk R. V. for valuable recommendations and consultations during the preparation of the manuscript.

The authors express their special gratitude to the director of the Rostov branch "Federal State Budgetary Institution" All-Russian Plant Quarantine Center Zhmyrko A.M.

\section{References}

1. J. T. Newitt, S. M. M. Prudence, M. I. Hutchings, S.F. Worsley Pathogens, 8(2), 78, 125 (2019), https://doi.org/10.3390/pathogens8020078.

2. U. Wachowska, D. Packa, M. Wiwart, Toxins, 9(12), 408, (2017) https://doi.org/10.3390/toxins9120408.

3. N. Grebenikova, A. Korshunov, V. Rud, I. Savchenko, M. Marques, MATEC Web of Conferences, 245, 11006 (2018) https://doi.org/10.1051/matecconf/201824511006.

4. A.P. Glinushkin, A.V. Ovsyankina, M.I. Kiseleva, et al. Distribution of Fungi from the Genus Fusarium Link. on Cereals. Russ. Agricult. Sci., 44, 235-240 (2018). https://doi.org/10.3103/S1068367418030059.

5. A. Femeniasa, F. Gatiusb, A. J. Ramosa, V. Sanchisa, S. Marína, Food Control, 108, February (2020) https://doi.org/10.1016/j.foodcont.2019.106819

6. K. Kazan, D. M. Gardiner, Molecular Plant Pathology, 19, 1547-1562 (2018) https://doi.org/10.1111/mpp.12639

7. A.A. Vasilenko, N.S. Kozulina, Z.N. Shmeleva, The assessment of the bioecological method use for spring barley cultivation in the Krasnoyarsk territory forest-steppe zone, AGRITECH Scopus IOP Conf Ser.: Earth Environ. Sci. 315022047 (2019) https://doi.org/10.1088/1755-1315/315/2/022047.

8. N. S. Kozulina, et al., 2020 IOP Conf. Ser.: Earth Environ. Sci. 548 (2020) doi:10.1088/1755-1315/548/4/042020.

9. A.K. Machado, N.A. Brown, M. Urban, et al., Pest. Manag. Sci, 74, 790-799, (2018), https://doi.org/10.1002/ps.4748

10. E. Oldenburg, F. Höppner, F. Ellne, J. Weinert, Mycotoxin Res 33, 167-182, (2017) http://DOI.org/10.1007/s12550-017-0277-y

11. A. Ficke, C. Cowger, G. Bergstrom, G. Brodal, Plant Disease , 102, 696-707 (2018) https://doi.org/10.1094/PDIS-09-17-1375-FE.

12. V. Spanic, Z. Zdunic, G. Drezner, B. Sarkanj, Toxins, 11, 198, (2019) https://doi.org/10.3390/toxins11040198. 
13. K. Gromadzka, L. Błaszczyk, J. Chełkowski, A. Waśkiewicz, Toxins, 11(4), 224, (2019) https://doi.org/10.3390/toxins11040224.

14. D.S. Gaikpa, T. Miedaner, Theor Appl Genet, 132, 2721-2739 (2019) https://doi.org/10.1007/s00122-019-03412-2

15. M. Zhou, L. Yang, M. Shao, Toxins (Basel), 10, 1-13 (2018) https://doi.org/10.3390/toxins10020049

16. V. Maschietto, C. Colombi, R. Pirona, BMC Plant Biol 17, 1-21, (2017), https://doi.org/10.1186/s12870-017-0970-1.

17. G.P. Kononenko, A.A. Burkin, E.V. Zotova, A.M. Smirnov, Rossiiskaia selskokhoziaistvennaia nauka, 3, 28-31, (2019), https://doi.org/10.31857/S250026272019328-31

18. A. Perczak, D. Gwiazdowska, K. Marchwińska, et al. Arch Microbiol, 201, 1085-1097 (2019) https://doi.org/10.1007/s00203-019-01673-5

19. Y. Tian, Y. Tan. N. Liu, et al., Front Microbiol, 7, 395, (2016) https://doi.org/10.3389/fmicb.2016.00395

20. A. Gorash, R. Armonienè, J. Mitchell Fetch, et al., Ann Appl Biol, 171, 281-302 (2017) https://doi.org/10.1111/aab.12375

21. F. Rasche, E. Blagodatskaya, C. Emmerling, et al., Ecosphere, 8(12), e02048 (2017) https://doi.org/10.1002/ecs2.2048

22. S. Sarrocco, A. Mauro, P. Battilani, State of Art and Future Perspectives, 11, 701 (2019), https://doi.org/10.3390/toxins11120701

23. V. Spanic, Z. Zdunic, G. Drezner, B. Sarkanj, Toxins, 11, 198, (2019), https://doi.org/10.3390/toxins 11040198

24. A.C. Felber, J.C. Polonio, R.C. Orlandelli, et al., Indian J Microbiol, 59, 217-224 (2019) https://doi.org/10.1007/s12088-019-00787-0 